\title{
Re-examination of the genus Omphalophloios White, 1898 from the Upper Silesian Coal Basin
}

\author{
STANISLAV OPLUŠTIL, JIŘí BEK \& STEPHAN SCHULTKA
}

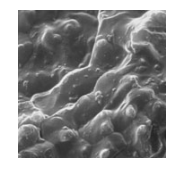

\begin{abstract}
Three specimens of the genus Omphalophloios White from the Upper Silesian Coal Basin are described. Two of them are type specimens of Sporangiostrobus orzeschensis Bode and S. rugosus Bode which represent fragments of fertile areas with microsporangia. Bode's specimens were revised to provide more precise data on their morphology and spores necessary for reliable comparison with other species of this genus. Only microspores were present. In situ microspores are variable and may be assigned to several dispersed species of the dispersed spore genus Densosporites (Berry) Butterworth et al. In situ densospores are closely comparable with previously described spores from other species of Omphalophloios. The two species distinguished by Bode (1928) on differences in spore morphology are ascribed to intraspecific variation. Additional criteria, which might justify retaining them as two different species were not found, since the cell pattern of the sporangial wall is essentially the same for all the species studied. Therefore, both species are synonymised and a new combination, Omphalophloios orzeschensis (Bode) comb. nov., is proposed and Sporangiostrobus Bode as the younger synonym of Omphalophloios. The third specimen studied is a vegetative stem fragment bearing Omphalophloios-type leaf cushions. Although the likelihood exists that it belongs to the same plant as the fertile remains, this cannot be proven. It is, therefore, described as a new species Omphalophloios bodei sp. nov. • Key words: Omphalophloios, Sporangiostrobus, Densosporites, lycopsid, Pennsylvanian.
\end{abstract}

OPLUŠTIL, S., BEK, J. \& SCHUltKA, S. 2010. Re-examination of the genus Omphalophloios White, 1898 from the Upper Silesian Coal Basin. Bulletin of Geosciences 85(1), 39-52 (8 figures, 2 tables). Czech Geological Survey, Prague. ISSN 1214-1119. Manuscript received April 27, 2009; accepted in revised form September 15, 2009; published online January 8, 2010; issued xxx xx, 2010.

Stanislav Opluštil, Charles University in Prague, Faculty of Sciences, Albertov 6, 12843 Praha 2, Czech Republic; oplustil@natur.cuni.cz•Jiři Bek, Department of Palaeobiology and Palaeoecology, Institute of Geology v.v.i., Academy of Sciences of the Czech Republic, Rozvojová 269, 16500 Praha 6, Czech Republic; mrbean@gli.cas.cz. - Stephan Schultka, Museum für Naturkunde zu Berlin, Invalidenstrasse 43, 10115 Berlin, Germany; stephan.schultka

In 1928, Bode described two fragmentary remains of fertile organs possessing large, rounded sporangia of several millimetres in size from which he obtained microspores. At that time, comparison could be made only with a similar fructification from the middle Westphalian strata of Bohemia, the Czech Republic, as figured by Feistmantel (1876) who determined it as Sigillariostrobus feistmantelii Feistmantel. Although Bode realized the incorrectness of Feistmantel's determination as Sigillariostrobus Schimper, he was not certain about the systematic position and could only state that they were of pteridospermous or pteridophytic affinity. Therefore, he established a new genus, Sporangiostrobus, and his specimens from the town of Orzesze (Orzesche in German) in Upper Silesia, Poland, were described as S. rugosus and S. orzeschensis. The reason for distinguishing two independent species was in the presumed differences in the morphology of the in situ microspores obtained from the two specimens.
Since that time, there has been significant progress in our knowledge regarding these unusual plants. Němejc (1931) provided the first thorough analysis and description of specimens from Bohemia and came to the conclusion that these fructifications were evidently lycopsid but more primitive than Lepidodendron Sternberg and Sigillaria Brongniart. He was also the first to recognise that this plant was heterosporous (bisexual) and that micro- and megasporangia are arranged in fertile areas and not cones. Němejc (1931) published the first microphotographs of in situ micro- and megaspores of Omphalophloios. Later, Chaloner $(1956,1962)$ recorded remains of this plant from North America and provided further morphological details. He assigned in situ microspores to Densosporites and in situ megaspores to Zonalesporites superbus (Bartlett) Karczewska. In 1970, Leisman published the first information about the anatomical structure of Sporangiostrobus and its in situ micro- and megaspores based on permineralized 
(coal-ball) specimens from Kansas, USA and provided an emended diagnosis. Later, based on an extensive collection from Puertollano in Spain, Wagner \& Spinner (1976) provided the first description of the vegetative part of Sporangiostrobus which they named Bodeodendron Wagner \& Spinner. Bek \& Straková (1995) published the first SEM photomicrographs of in situ densospores obtained from a fertile apex of Omphalophloios from the Bolsovian strata of the Kladno-Rakovník Basin, the Czech Republic, and gave a detailed description.

Brousmiche-Delcambre et al. (1995) identified Sporangiostrobus with White's (1898) lycopsid genus Omphalophloios based on impression specimens from Missouri, the USA. This means that Sporangiostrobus and Bodeodendron and also Puertollania Remy \& Remy are younger synonyms of Omphalophloios which can be applied to both vegetative and fertile parts (Table 1). It also significantly extends the geographical distribution of these primitive lycopsids. Brousmiche-Delcambre et al. (1995) macerated only megaspores of the Superbisporites-type from megasporangia. In 1996, Coquel and BrousmicheDelcambre provided a more thorough description of in situ microspores from Omphalophloios from Puertollano which they described as being of Cristatisporites-Densosporites-Cingulizonales-type.

Representatives of Sporangiostrobus/Omphalophloios occur from North America [O. cyclostigma (Lesquereux) White, S. kansanensis Leisman, S. langfordi Chaloner, S. ohioensis Chaloner] throughout the British Isles, Belgium and Germany [ $O$. anglicus (Sternberg) Kidston] to the Czech Republic [S. feistmantelii (Feistmantel) Němejc], central Spain [O. puertollanense (Remy \& Remy) Wagner et al.] and Upper Silesian in southern Poland (S. rugosus and S. orzeschensis). Remains of Omphalophloios occur from the early Westphalian to late Stephanian. However, their stratigraphic range is much shorter than that of the densospores which already appeared in the Devonian strata although being most abundant throughout the Pennsylvanian in most Euramerican coalfields. It is noted that Omphalophloios is not the only densospore-producer because this type of microspore also occurs in some cones of herbaceous lycopsids (Bharadwaj 1958) (Table 2). Early Pennsylvanian (Namurian B) seams of the Saddle Beds in the Czech part of the Upper Silesian Coal Basin are locally dominated by densospores which make up more than $90 \%$ of all spores in some samples (e.g., Bek 2008). These coals are up to $10 \mathrm{~m}$ thick (e.g., the Prokop Seam) which indicates the importance of these plants as biomass contributors to peat. They usually occur in inertinite-rich dull coal lithotypes (duritic coals) which suggest a strong ecological link to relatively dry types of mires (see Eble \& Grady 1990). Smith (1962) and Smith \& Butterworth (1967) assigned such densospore-dominated parts of coal seams to their densospore phase which they interpreted as the ombrotrophic stage of mire development as is also supported by the high inertinite and very low mineral matter content. On the other hand, different authors (e.g. Littke 1987, Strehlau 1990, Opluštil et al. 1999) identified a densospore phase from coal seams which contained sedimentary partings or increased ash content and which evidently, did not develop into an ombrotrophic mire. Eble \& Grady (1990) suggested an ecological link between densospore-producing plants and brackish conditions. A coastal salt-marsh environment is suggested for $O$. puertollanense (Wagner et al. 2003).

However, to understand fully the ecological significance of this genus, as well as its intra-generic variability, requires a revision of all the species known so far. Unfortunately, remains of Omphalophloios are quite rare with the notable exceptions of Puertollano (central Spain) and central Bohemian (Czech Republic) coalfields. Only three such specimens have been found so far in the Upper Silesian Coal Basin. These findings are the main scope of this contribution, based on the re-examination of Bode's two holotypes and the maceration and description of their in situ spores using scanning electron microscopy (SEM).

\section{Material and methods}

The three specimens referred to are stored in the collections of the Humboldt Museum für Naturkunde, LeibnizInstitute for Research on Evolution and Biodiversity at the Humboldt Universität Berlin. Two of these are Bode's (1928) specimens of Sporangiostrobus rugosus (Inv. No. MB.Pb. 2003/0883) and Sporangiostrobus orzeschensis (Inv. No. MB.Pb. 1987/0368). Both come from the town of Orzesze in Upper Silesia in southern Poland and represent fragments of fertile areas with sporangia. The third specimen (Inv. No. MB.Pb. 2009/0047) is part of a vegetative stem (Bodeodendron sensu Wagner \& Spinner 1976) which has not been previously published. This specimen is also from Orzesze in Upper Silesia. Stratigraphically all three specimens originate from the Orzesze Beds (Duckmantian) in the upper part of the Mudstone Series. Bode's specimens were re-examined under a binocular microscope to find out whether they bear only microsporangia or also megasporangia. Unfortunately, only microsporangial parts are present in both specimens. From Bode's specimens, one sporangium from $S$. rugosus and two sporangia from $S$. orzeschensis were taken for maceration. Prior to maceration, their surface was scanned by electron microscopy to observe the cellular pattern of the sporangial wall. A sporangium of S. rugosus was scanned under low vacuum by the JEOL JSM-6380 Scanning electron microscope at the Department of Geology and Palaeontology of the Faculty of Science, Charles University, 
Table 1. The overview of morphotaxa related to genera Omphalophloios/Sporangiostrobus.

\begin{tabular}{lll}
\hline Genus & Original interpretation & Current interpretation \\
\hline Omphalophloios & $\begin{array}{l}\text { Vegetative stems with two different types of leaf } \\
\text { cushions and leaf scars (White 1898) }\end{array}$ & $\begin{array}{l}\text { Generic name used for vegetative and disarticulated fertile remains of one } \\
\text { and the same plant (Brousmiche-Delcambre } \text { et al. 1995) }\end{array}$ \\
Sporangiostrobus & Fertile organ of pteridophytic affinity (Bode 1928) & $\begin{array}{l}\text { Synonym for fertile stem apex of } \text { Omphalophloios (Brousmiche-Delcambre } \\
\text { et al. 1995) }\end{array}$ \\
Bodeodendron & $\begin{array}{l}\text { Vegetative stem of Sporangiostrobus (Wagner \& } \\
\text { Spinner 1976) }\end{array}$ & $\begin{array}{l}\text { Synonym for vegetative stem of } \text { Omphalophloios (Brousmiche-Delcambre } \\
\text { et al. 1995) }\end{array}$ \\
& $\begin{array}{l}\text { Vegetative branches of Sporangiostrobus (Remy \& } \\
\text { Remy 1975) }\end{array}$ & $\begin{array}{l}\text { Disarticulated fertile stem without sporangia and showing proximal parts of } \\
\text { sporophylls (Wagner \& Spinner 1976) }\end{array}$ \\
\hline
\end{tabular}

Table 2. The overview of in situ spores isolated from Omphalophloios, Sporangiostrobus, and Sigillariostrobus (Si).

\begin{tabular}{|c|c|c|c|c|}
\hline Plant species & Microspores & Megaspores & Stratigraphy & References \\
\hline Si. cordai & - & Unnamed & Bolsovian & Feistmantel (1875/6) \\
\hline S. orzeschensis & Unnamed & - & Bolsovian & Bode (1928) \\
\hline S. rugosus & Unnamed & - & Bolsovian & Bode (1928) \\
\hline S. feistmantelii & Unnamed & Triletes zonales & Bolsovian & Němejc (1931) \\
\hline S. cordai & - & Unnamed & Bolsovian & Němejc (1931) \\
\hline S. langfordii & - & $\begin{array}{l}\text { Zonalesporites } \\
\text { superbus }\end{array}$ & Asturian & Chaloner (1956) \\
\hline S. ohioensis & Cristatisporites solaris & $\begin{array}{l}\text { Zonalesporites } \\
\text { superbus }\end{array}$ & Langsettian & Chaloner (1962) \\
\hline S. kansanensis & $\begin{array}{l}\text { Radiizonates rotatus, } R \text {. aligerens, Cingulizonates, Vallatisporites, } \\
\text { Cristatisporites, Densosporites simplex, } \\
\text { D. intermedius }\end{array}$ & Zonalesporites & & Leisman (1970) \\
\hline S. puertollanensis & Densosporites & - & Stephanian C & Remy \& Remy (1975) \\
\hline S. feistmantelii & $\begin{array}{l}\text { Densosporites cf. spinifer, D. spinifer, D. granulosus, D. lobatus, } \\
\text { D. sphaerotriangularis, D. glandulosus, D. pseudoannulatus, D. } \\
\text { anulatus, D. gracilis, Cristatisporites cf. saarensis }\end{array}$ & - & Bolsovian & Bek \& Straková (1995) \\
\hline S. feistmantelii & $\begin{array}{l}\text { Densosporites granulosus, D. lobatus, D. sphaerotriangularis, } \\
\text { D. gracilis, D. spinifer, D. cf. spinifer, D. anulatus, D. glandulosus, } \\
\text { D. pseudoannulatus, D, regalis, D. cf. major, D. triangularis, } \\
\text { Cristatisporites splendidus, C. indignabundus, C. saarensis, C. solaris, } \\
\text { C. connexus }\end{array}$ & $\begin{array}{l}\text { Zonalesporites } \\
\text { superbus }\end{array}$ & Bolsovian & Bek (1998) \\
\hline S. feistmantelii & $\begin{array}{l}\text { Densosporites lobatus, Cristatisporites indignabundus, } \\
\text { C. solaris, C. saarensis }\end{array}$ & - & Bolsovian & Bek \& Opluštil (1998) \\
\hline O. cyclostigma & - & Superbisporites & Asturian & $\begin{array}{l}\text { Brousmiche-Delcambre } \\
\text { et al. }(1995)\end{array}$ \\
\hline Omphalophloios & Densosporites, Cristatisporites, Cingulizonates & - & Stephanian C & $\begin{array}{l}\text { Coquel \& } \\
\text { Brousmiche-Delcambre } \\
\text { (1996) }\end{array}$ \\
\hline O. rugosus & Densosporites & - & Bolsovian & Herein \\
\hline O. orzeschensis & Densosporites & - & Bolsovian & Herein \\
\hline O. puertollanense & Cristatisporites & Zonalesporites & Stephanian C & Wagner et al. (2003) \\
\hline
\end{tabular}

in Prague. SEM pictures of another sporangium of $S$. rugosus and that of $S$. orzeschensis were taken by a JEOL JSM 6300 after being sputtered with gold-palladium at the Museum für Naturkunde, Leibniz-Institute for Research on Evolution and Biodiversity at the Humboldt Universität Berlin.

Spores were recovered by dissolving small portions of sporangia with the aid of nitric acid for 24-40 hours followed by potassium hydroxide for 1 hour. Most spores were mounted in glycerine jelly for direct microscopic examination. Some spores were examined under CAMECA SX100 scanning electron microscope. Photomicrographs were made using a digital camera, Olympus C330s, and under an Olympus BX51 microscope. The terminology 

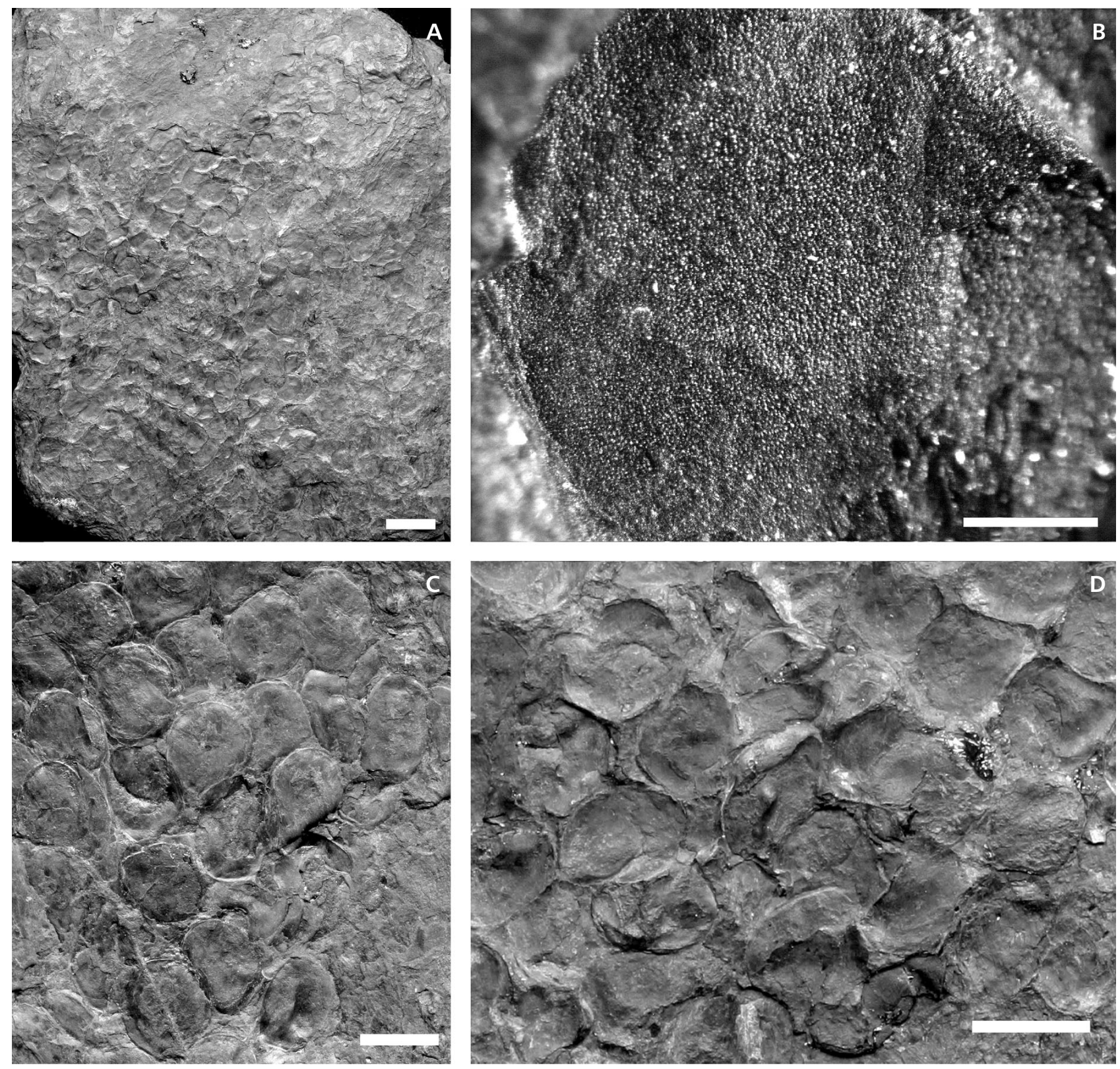

Figure 1. Omphalophloios orzeschensis (Bode) comb. nov. emend. • A - view of Bode's holotype of Sporangiostrobus orzeschensis (Inv. No. MB.Pb. 1987/0368), scale bar $10 \mathrm{~mm}$. B - detail of sporangium showing fine "granulate" surface. Scale bar $0.5 \mathrm{~mm}$. $\bullet$ C - detail of imbricated microsporangia with rim, scale bar $5 \mathrm{~mm}$. D - detail of different part of the same specimen with imbricated sporangia. Note the folds formed mostly by overprinting of overlapping sporangia. Scale bar $5 \mathrm{~mm}$.

used for the descriptions of in situ spores is the same as that in the latest edition of the Glossary of pollen and spore terminology (Punt et al. 2007). In situ spores are compared according to the system of classification of dispersed spores suggested by Potonié \& Kremp (1954, 1955), Dettmann (1963) and Smith \& Butterworth (1967). Slides and digital photomicrographs of the microspores are stored in the Laboratory of Palaeobiology and Palaeoecology, Institute of Geology v.v.i., Academy of Sciences, Prague.

\section{Discussion of Bode's species}

Bode (1928) described two fertile specimens as two independent species. As the main criterion for this separation he discussed the nature of the spores. Those of $O$. orzeschensis he called "glatterer", i.e. smooth or glossy, whereas spores of $O$. rugosus he described as "rauher", i.e. rough. However, detailed re-examination of both specimens and their spores revealed that macerated in situ microspores from both species are closely similar, i.e. no 
sculptural differences (based on SEM observations) as supposed by Bode. All may be assigned to the dispersed spore genus Densosporites. It is possible to assign these in situ densospores to several dispersed species of this genus due to variations in amb, shape, number and type of sculpture elements. Macerated densospores from O. orzeschensis are generally somewhat smaller and do not possess such prominent sculpture on the proximal surface of the central body in comparison with those of $O$. rugosus. However, from a palynological point of view, both sets of in situ densospores are identical. This result is not surprising since similar observations were made by Wagner (1989) and in particular by Bek \& Opluštil (1998), and by Bek \& Straková (1996) who obtained several species of densospores from a single sporangium. Therefore, using microspores as a means of separating these species, as suggested by Bode, is inappropriate. Both remains represent only microsporangiate fragments. Thus, the only way to confirm whether these two specimens really represent two different species is by a careful re-examination of the sporangia. Unfortunately, the sporangia of both species, as well as in most other Sporangiostrobus/Omphalophloios species, are indistinguishable to the naked eye. High magnification (SEM) shows differences in the structure of sporangial surfaces of both species. Reticulation observed on the surface of S. orzeschensis sporangia is much more prominent, and its meshes are generally larger, up to $58 \times 45 \mu \mathrm{m}$. This reticulation in $S$. orzeschensis is much less apparent and of a different type on the equatorial rim (Fig. 2B). The reticulation of $S$. rugosus is much less prominent and locally even indistinct (Fig. 4D-F). The largest meshes measure about $35 \times 45 \mu \mathrm{m}$.

The nature of the reticulation on the sporangial surface became obvious when comparing this pattern with the cuticles figured by Bode (1928) and Němejc (1931). Reticulation observed under SEM strongly resembles the polygonal cell pattern figured by both authors. Therefore, it is interpreted here as an epidermal cell structure. Although Bode's figures are too poor for a detailed comparison, the cell pattern of his species displays similar polygonal "meshes" as those observed on the sporangium under SEM. Their size, however, can be slightly different. Cells of S. rugosus, as figured by Bode (1928, fig. 1a), are polygonal and often two or three times longer than wide. The largest are about $40 \mu \mathrm{m}$ long. Those of $S$. orzeschensis are also polygonal but seem to be generally elongate. The largest cells are also about $40 \mu \mathrm{m}$ long which is a little less than the maximum size observed on the sporangial surface of this specimen under SEM. Cuticles figured by Němejc (1931) from sporangia of $S$. feistmantelii also clearly display a polygonal cell pattern resembling that on the surface of sporangia in Bode's species, as observed under SEM. The size of cells in all these species are also comparable. Němejc's
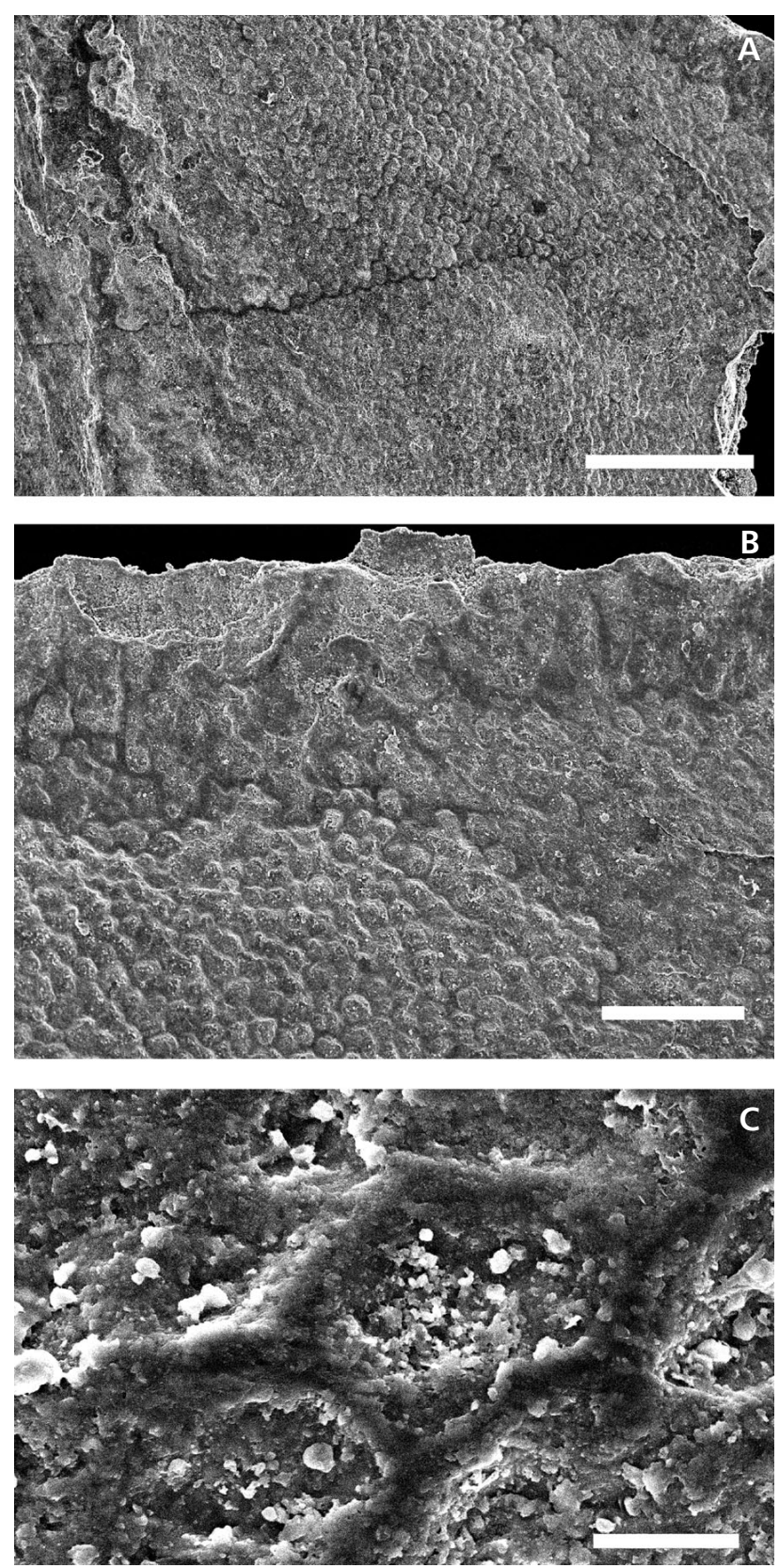

Figure 2. Omphalophloios orzeschensis (Bode) comb. nov. emend; MB.Pb. 1987/0368, SEM. • A - cell pattern on sporangium surface. Scale bar $700 \mu \mathrm{m}$. $\bullet B$ - cell pattern on sporangium surface. Note the difference on equatorial rim (right top). Scale bar $300 \mu \mathrm{m}$. $\bullet \mathrm{C}$ - detail of cell pattern in central part of sporangium. Scale bar $30 \mu \mathrm{m}$.

(1931) figures 9-12 also clearly show the range of variability of cells in term of their length/width ratio.

Some cells are either as long as they are wide as or only slightly longer than their width, whereas others (especially Fig. 9) are two or nearly three times longer. The size of cells varies between 30 and $40 \mu \mathrm{m}$ on average, even though some cells are up to $55 \mu \mathrm{m}$ long. This also indicates that the differences in the size of polygonal cells 
and their length/width ratio are most probably related to the between species distinction. Also the prominence of the "mesh pattern" observed on the sporangial surface under SEM and interpreted as cell pattern, seems to be a matter of preservation quality. As a result of these observations, it is possible to state that Bode's (1928) criteria on which he established his two different species, cannot be maintained. Neither is it possible to use the cell pattern on sporangial walls as a criterion to justify Bode's species. Since no serious differences can be found, we consider both of Bode's specimens as representing only one species. This is further supported by the fact that both specimens came from the same locality. Therefore, we synonymize both species and use the name $S$. orzeschensis. However, because Brousmiche-Delcambre et al. (1995) proved that Sporangiostrobus and Omphalophloios represent the same plant, the new combination, O. orzeschensis, is proposed here.

\section{Systematic section}

Class Lycopsida Scott, 1909

Order Isoetales Engler, 1924

\section{Genus Omphalophloios White, 1898}

Type species. - Omphalophloios cyclostigma (Lesquereux) White, 1898.

Omphalophloios orzeschensis (Bode, 1928) comb. nov.

1928 Sporangiostrobus orzeschensis n. sp.; Bode; p. 247, fig. 1.

1928 Sporangiostrobus rugosus n. sp.; Bode; p. 247, fig. 2.

Holotype. - Specimen Inv. No. MB.Pb. 1987/0368, deposited in the palaeontological collection of the Museum für Naturkunde, Leibniz-Institute for Research on Evolution and Biodiversity at the Humboldt-Universität Berlin.

Material. - In addition to the holotype, there is another specimen deposited in the same collection which is the holotype of Bode's (1928) S. rugosus.

Locality. - Both specimens are from the same locality; the village of Orzesze in Upper Silesia, southern Poland.

Stratigraphy. - Orzesze Beds (Duckmantian), Mudstone Series.

Emended diagnosis. - Sporangia circular in outline, discus-like, imbricate, arranged into parastiches. Sporangia surface smooth, cells of sporangium wall polygonal, with straight anticlinal walls, mostly slightly longer than wide, between 30 and $50 \mu \mathrm{m}$ on average. Trilete cingulate microspores with oval, circular to subtriangular amb. Proximal surface strongly cristate, rugulate. Trilete mark equal to the diameter of the central body. Proximal surface of cingulum laevigate, finely scabrate, occasional spinae occur. Proximal surface of the central body laevigate to finely scabrate.

Description. - Since there are only two specimens, their descriptions are provided separately. The first to be considered is the specimen Inv. No. MB.Pb. 1987/0368, which is selected here as the holotype of $O$. orzeschensis. It is a fragment of a fertile axis preserved as a compression and partly as an impression of sporangia in clayey coal, forming a thin parting within a coal seam (Fig. 1A). The sporangia cover a continuous, but irregular area of about $8 \times 10$ $\mathrm{cm}$ except for a few isolated (?dispersed) sporangia in the vicinity. The irregular shape indicates that no original margin of the fertile stem is preserved and that the diameter of the stem had to be more than $8 \mathrm{~cm}$. Sporangia are arranged without any tendency towards a progressive change in their size in any given direction. They are densely packed, forming parastichies. Neighbouring sporangia are imbricated (Fig. 1C, D). The zone of overlap can be up to $2 \mathrm{~mm}$ wide. The rounded to slightly oval and flattened disc-like microsporangia range between $4 \times 4.2 \mathrm{~mm}$ and $6 \times 4.8 \mathrm{~mm}$ in size. However, the differences in size may be a taphonomic effect depending on the degree of flattening due to compression as indicated by the irregular distribution of sporangia of various sizes. Most sporangia are smooth, except for "wrinkles" which can be observed by the naked eye and often result from overprinting of the outline of overlapping sporangia (Fig. 1D). However, under high magnification, a polygonal cell pattern became visible (Fig. 1B). Some cells are up to $58 \mu \mathrm{m} \times 45 \mu \mathrm{m}$ in size although the average length varies between 40 and $50 \mu \mathrm{m}$ (Fig. 2). On the ca $600 \mu \mathrm{m}$ wide equatorial rim, the net-like structure begins to disappear and merges into grooves of varying width running towards the edge (Fig. 2B).

Microspores obtained from this specimen are mostly with a triangular to subtriangular amb although oval and circular ones also occur. The total size is 40 (47) $52 \mu \mathrm{m}$, the cingulum is from 7 to $11 \mu \mathrm{m}$ wide. The whole distal surface is densely covered by several sculptural elements of variable height, width and shape (Fig. 3B, D). Sculptural elements can be connected and produce a prominent cristate sculpture. Some sculptural elements possess small verrucae, usually located at their apex (Fig. 3B, D).

The second specimen, i.e. Bode's (1928) holotype of $S$. rugosus (MB.Pb. 2003/0883) is a $62 \mathrm{~mm}$ long and $37 \mathrm{~mm}$ wide fragment of the microsporangiate part of the fertile area, preserved in grey mudstone from the roof of the coal seam (Fig. 4A). No original margin of the fertile axis has been preserved. Sporangia are flattened or disc-like in shape, 

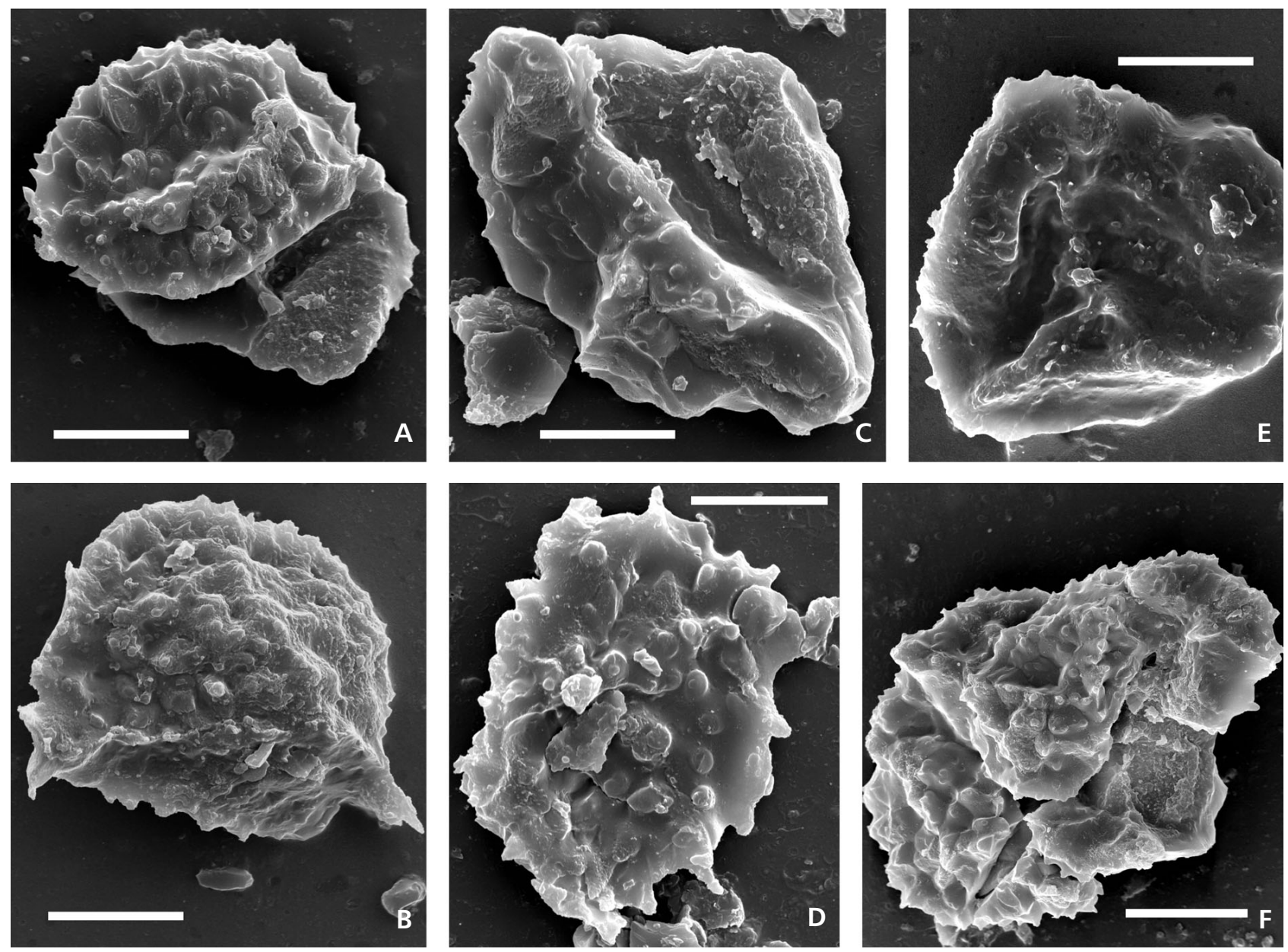

Figure 3. Omphalophloios orzeschensis (Bode) comb. nov. emend.; all microspores from the holotype, MB.Pb. 1987/0368. • A - two in situ microspores of the Densosporites-type. Note spinate to conate sculpture of the distal surface of the specimen on the right and laevigate to finely scabrate proximal surface of the second specimen (left). Scale bar $20 \mu \mathrm{m}$. • B, D - in situ microspores of the Densosporites-type. Distal surfaces. Scale bar $20 \mu \mathrm{m}$. - $\mathrm{C}$ - in situ microspore of the Densosporites-type. Lateral view showing the difference between the strongly spinate, conate sculpture of the distal surface (left) and laevigate to finely scabrate proximal surface (right). Scale bar $20 \mu \mathrm{m}$. $\bullet$ E - in situ microspore of the Densosporites-type. Proximal surface with trilete mark. Scale bar $20 \mu \mathrm{m}$. $\bullet \mathrm{F}$ - two incomplete tetrads of in situ microspores of the Densosporites-type. Note different sculpture of distal and proximal surfaces on specimens from upper incomplete tetrade. Scale bar $50 \mu \mathrm{m}$. All SEM.

more or less circular in outline and between 5 and $5.6 \mathrm{~mm}$ in diameter (Fig. 4B). They are arranged into parastichies and are imbricate so that the margin of a sporangium is overlapped by the sporangium below and overlaps in turn another sporangium higher up in the parastichi. Similar overlap also occurs in the perpendicular rows. The zone of overlap varies between $0.4-0.7 \mathrm{~mm}$ but is usually closer to the lower value. The outlines of overlapping sporangia are often overprinted on the surface of the adjacent sporangium. To the naked eye, sporangia show an almost smooth surface, possibly with some projections in the middle of the sporangium (Fig. 4C). However, under higher magnification, the surface of the compressions exhibit small flat grooves forming a reticulate structure which is interpreted as the anticlinal walls delimiting cells. This structure becomes less prominent towards the rim of the sporangium (Figs 4D-F, 5). The largest polygonal cells measure $20 \mu \mathrm{m} \times 30 \mu \mathrm{m}$.
Microspores are mostly with a triangular to subtriangular amb although oval and circular outlines also occur (Figs 6, 7). The total size is 41 (52) $62 \mu \mathrm{m}$, the cingulum is from 6 to $11 \mu \mathrm{m}$ wide. The whole distal surface is densely covered by several sculptural elements of variable height, width and shape. Sculptural elements can be connected and can produce a prominent cristate sculpture. Some sculptural elements possess small verrucae usually located at their apex.

Remarks. - All in situ microspores macerated from sporangia can be identified with more than one species of the genus Densosporites.

Comparisons of Bode's specimens. - The morphology of fertile remains of all the currently known species of Omphalophloios is very similar including their in situ spores. They display flattened disc-like and imbricate sporangia arranged 
into parastichies. The cell pattern observed on some sporangia is also very similar and no significant differences have been observed. As already mentioned, the in situ microspores are generally of the same type and do not provide reliable criteria for distinguishing species. Unfortunately, no megaspores are preserved in Bode's specimens. The size of sporangia is also more or less the same within each specimen and also among most species of the genus, except $O$. puertollanense (Remy \& Remy) Wagner et al. and S. kansanensis Leisman which are up to about twice the size of those of all other species. Representatives of the genus Omphalophloios occur in strata ranging from the Duckmantian to Stephanian C.

Taking into account all the above-mentioned characteristics, $O$. orzeschensis is most similar to S. feistmantelii from central and western Bohemia, the Czech Republic. Both species are also of very similar age; $O$. orzeschensis is of Duckmantian age whereas $S$. feistmantelii is early Bolsovian. Their sporangia are also of similar size; the holotype (MB.Pb. 1987/0368) of O. orzeschensis has sporangia about 4.5-5.5 $\mathrm{mm}$ in diameter and those of the specimen MB.Pb. 2003/0883 (Bode's holotype of S. rugosus) are 4.9-5.6 mm in diameter. Sporangia of S. feistmantelii are between 5 and $6 \mathrm{~mm}$ in size. Concerning the sporangial cell pattern, it was compared with that of sporangia of $S$. feistmantelii as figured by Němejc (1931). His figures clearly show irregularly polygonal cells, mostly only slightly longer than they are wide, although cells which are as long as they are wide, or two or three time longer than wide are also quite common, probably depending on their position on the sporangium. The average size of cells, as measured from Němejc's figures, is between 30 and $40 \mu \mathrm{m}$ which corresponds with cells observed in $O$. orzeschensis.

Bode's specimens differ from $O$. puertollanense in being generally smaller. Sporangia of $O$. puertollanense are about $10 \mathrm{~mm}$ in length whereas those of $O$. orzeschensis from the Upper Silesian Coal Basin are much smaller, being not larger than $5.5 \mathrm{~mm}$. This size is related to fully mature sporangia with ripe spores. Moreover, O. puertollanense is much younger being of latest Pennsylvanian age (late Stephanian C) whereas Bode's specimens come from the middle Pennsylvanian (Duckmantian), i.e. about 10 Ma older.

Comparison with the late Westphalian or early Stephanian American species, O. cyclostigma, shows that Bode's and the American species have rounded and slightly imbricate sporangia of comparable size, i.e. about 5-5.5 mm, arranged into parastichies. Unfortunately, all the known fertile specimens of $O$. cyclostigma contain only megaspores which excludes a meaningful comparison between spores because only microspores are known from $O$. orzeschensis.

In situ microspores from Omphalophloios. - The first reference of in situ microspores from plants of the Omphalophloios-type was published by Bode (1928) who described microspores from the specimens studied herein (his
Sporangiostrobus). Němejc (1931) was the first to illustrate in situ megaspores and also the first to mention the bisporangiate character of Omphalophloios. Later authors (Table 2) isolated in situ micro- and megaspores from plants of this type. All in situ microspores belong to the cingulate spore group known as densospores, i.e. morphologically similar spore genera usually of the Densosporites, Cristatisporites and Cingulizonates-types. In situ megaspores are also morphologically similar and are referred to the zonate genera Zonalesporites (Ibrahim) Potonié \& Kremp, Superbisporites Potonié \& Kremp and maybe Rotatisporites (Ibrahim) Dybova-Jachowicz et al.

Leisman (1970) mentioned the morphological variability of in situ densospores and compared in situ spores from a permineralized specimen of $S$. kansanensis with the dispersed genera Densosporites, Cristatisporites, Cingulizonales Dybová \& Jachowicz, Vallatisporites Hacquebard and Radiizonates Staplin \& Jansonius (Table 2).

Microspores isolated from species of Omphalophloios are morphologically quite variable. It is possible to compare in situ microspores from single sporangium with several dispersed species belonging to different genera (Table 2). Spores isolated from microsporangia close to the apex are generally smaller (usually $50 \%$ smaller) than those macerated from microsporangia more distant from the apex and closer to the base of the fertile apex (Bek \& Straková 1995). This can be explained by different stages of maturity of smaller forms. Wagner et al. (2003) pointed out that the disarticulation of fertile apices (on maturity) commenced in the basal part of the fertile area.

\section{Omphalophloios bodei sp. nov.}

Holotype. - Specimen MB.Pb. 2009/0047, deposited in the palaeobotanical collections of the Museum für Naturkunde, Leibniz-Institute for Research on Evolution and Biodiversity at the Humboldt Universität Berlin.

Material. - Only the holotype.

Locality. - Orzesze in Upper Silesia, southern Poland.

Stratigraphy. - Orzesze Beds (Duckmantian), Mudstone Series.

Etymology. - In honour of H. Bode, a German palaeobotanist who first described specimens of the genus Omphalophloios (Sporangiostrobus) from the Upper Silesian Coal Basin.

Diagnosis. - Leaf cushions in parastichies, rhomboidal, slightly asymmetrical, with flat and smooth surface, rounded lateral angles and upper and lower ends gently inflected in opposite directions. Leaf cushions separated by discontinuous 

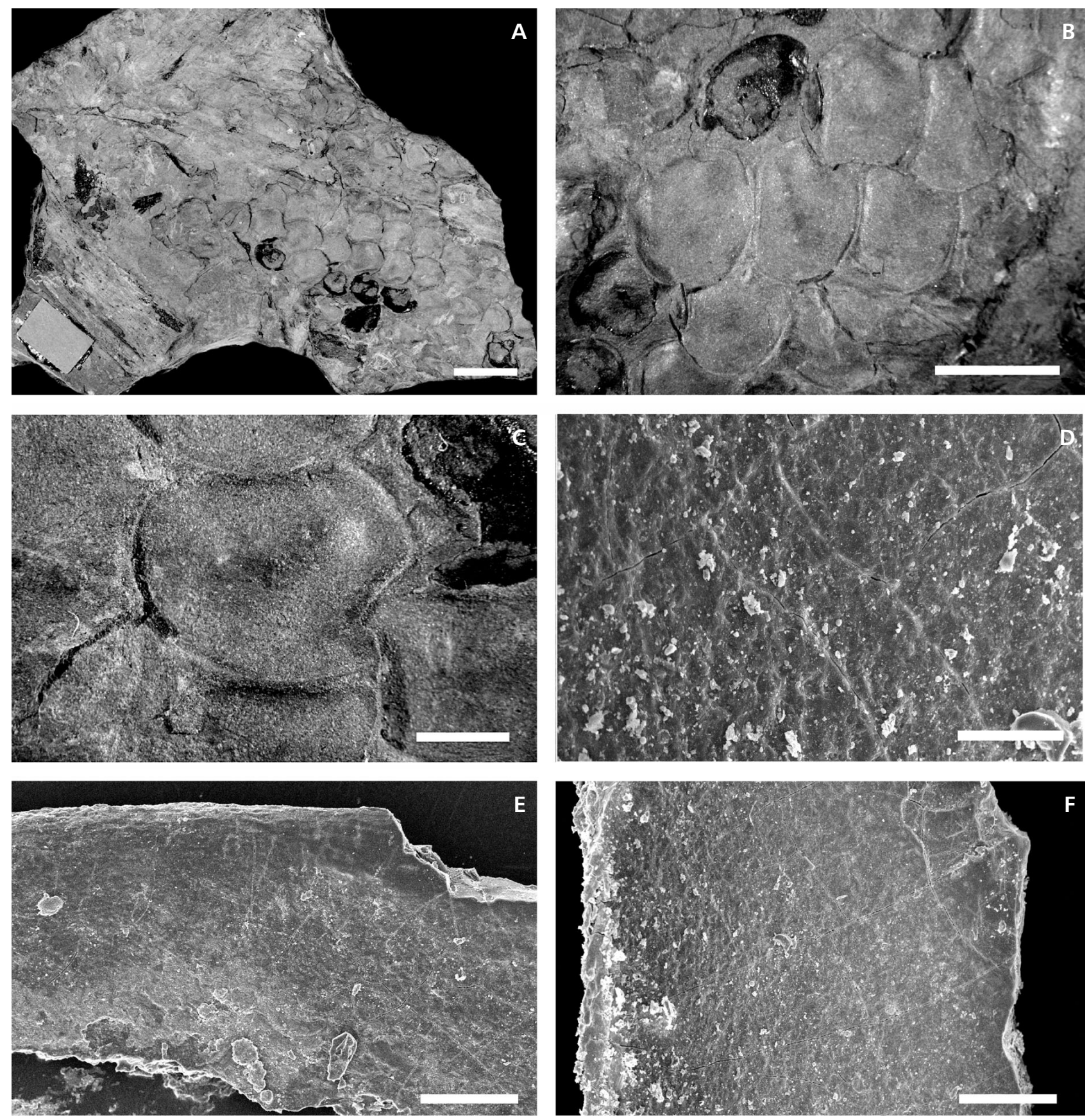

Figure 4. Omphalophloios orzeschensis (Bode) comb. nov. emend. • A - holotype of Sporangiostrobus rugosus (MB.Pb. 2003/0883). Scale bar $10 \mathrm{~mm}$. B - detail of imbricated microsporangia, scale bar $5 \mathrm{~mm}$. $\bullet$ - detail of microsporangium from the central part of Fig. 4B. Scale bar $2 \mathrm{~mm}$. -D - detail of cell pattern on sporangium surface. Scale bar $100 \mu \mathrm{m}$. E - detail of cell pattern on sporangium surface. Note the different meshes on the equatorial rim. Scale bar $300 \mu \mathrm{m}$. $\bullet \mathrm{F}$ - detail of the pattern of meshes on the sporangium surface. Scale bar $300 \mu \mathrm{m}$. D-F: SEM, low vacuum.

line. Leaf scar sub-triangular to bell-shaped, slightly wider than long, with single vascular bundle marking in lower part. Leaf scar located in the middle of the leaf cushion or slightly above, occupying nearly $2 / 3$ of the leaf cushion width.

Description. - The specimen, preserved as a compression in mudstone, is a $90 \mathrm{~mm}$ wide and $160 \mathrm{~mm}$ long vegetative stem fragment, which displays the outline of rhomboidal and slightly asymmetrical leaf cushions with rounded lateral angles (Fig. 8A, B). The upper and lower ends are slightly inflected in opposite directions. Each leaf cushion merges continuously into the leaf cushion above and below it (Fig. 8A, B). The leaf cushions are flat, smooth, without a keel and lacking parichnos markings (Fig. 8C, D). They are sepa- 

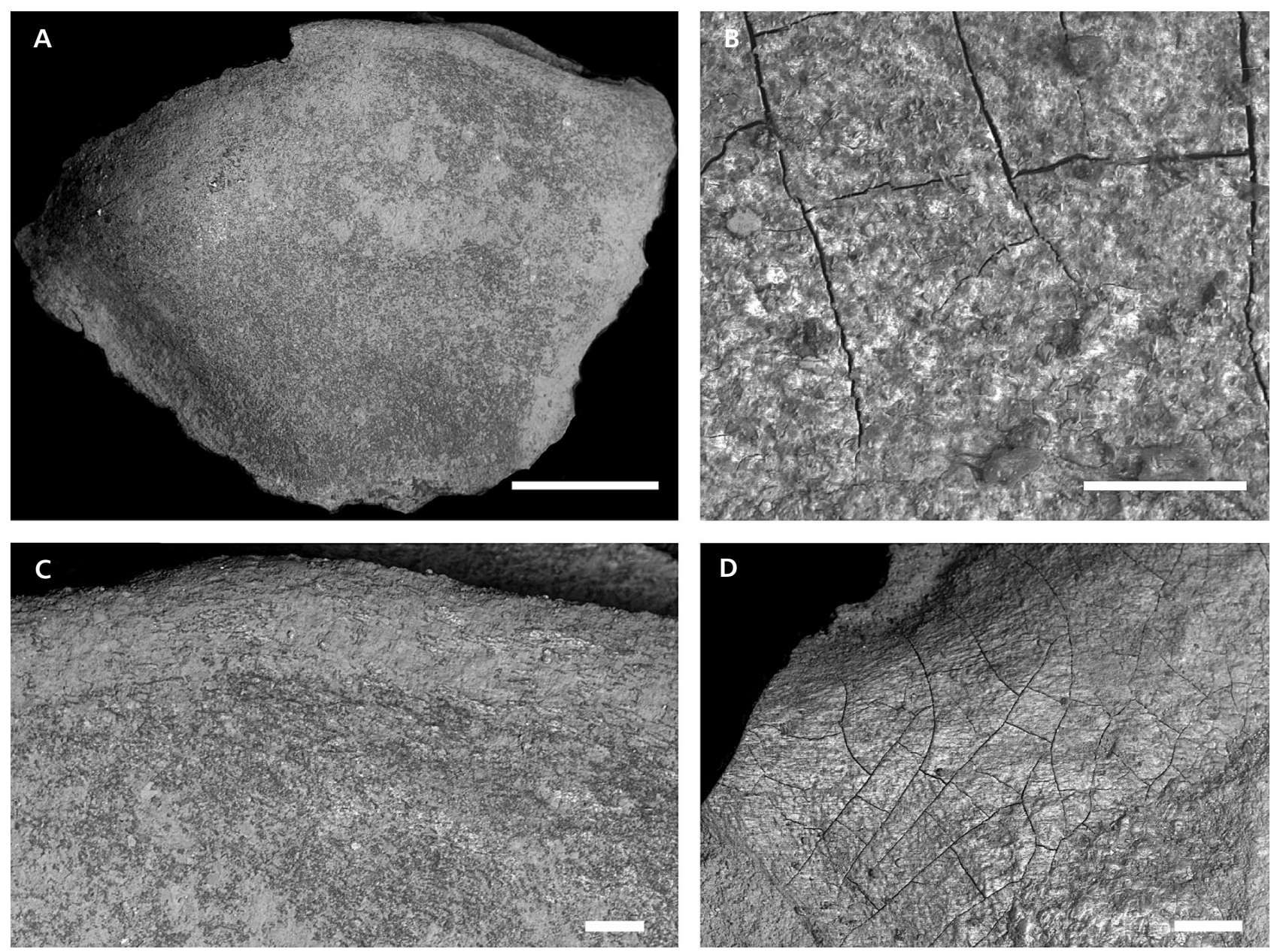

Figure 5. Omphalophloios orzeschensis (Bode) comb. nov. emend.; MB.Pb. 2003/0883. All figures SEM, low vacuum. • A - adaxial side of sporangium surface. Scale bar $1 \mathrm{~mm}$. $\bullet \mathrm{B}$ - detail of cell pattern on abaxial side of the sporangium surface. Scale bar $100 \mu \mathrm{m}$. $\bullet \mathrm{C}-$ detail of marginal part of adaxial side of the sporangium with equatorial rim. Scale bar $100 \mu \mathrm{m}$. $\bullet \mathrm{D}$ - detail of abaxial side of the sporangium surface. Scale bar $200 \mu \mathrm{m}$.

rated only by thin and discontinuous lines and are arranged into parastichies. The leaf cushions are about 10 to $12 \mathrm{~mm}$ long and between 5 and $6 \mathrm{~mm}$ wide. They attain their maximum width slightly below the middle of the leaf cushion. The subtriangular to slightly bell-shaped leaf scars with slightly raised margins are 3.5-4.5 mm wide and 2.8-3.2 $\mathrm{mm}$ long depending on their position on the stem (Fig. 8C, D). Near the margin of the flattened stem remains, they become narrower as do the leaf cushions. They are located nearly in the middle of the leaf cushion or slightly above it.

In the distal area of the bell-shaped scars there is only one small vascular bundle, which sometimes appears as if split into two (Fig. 8C, D). Often there is a distinct depression in the middle of the top of the leaf cushion above the leaf scar, which may mark the position of a ligula pit (Fig. 8C). The cell pattern observed on the leaf cushion under SEM (Fig. 8E) displays polygonal (mostly irregularly hexagonal) cells either only slightly longer than they are wide or up to twice as long as they are wide. The majority of cells are about 40-45 $\mu \mathrm{m}$ wide and 50-80 $\mu \mathrm{m}$ long.
Discussion. - Vegetative stems of Omphalophloios (Bodeodendron) are usually characterized by raised leaf cushions with rounded to bell-shaped leaf scars (Wagner \& Spinner 1976, Brousmiche-Delcambre et al. 1995). However, the specimen from Orzesze has flat leaf cushions which is less typical for the vegetative axis of this lycopsid. Therefore this species also slightly resembles some specimens identified by Brousmiche-Delcambre et al. (1995) as a fertile axis without sporangia, in its final stage of disintegration. Nevertheless, specimens with flat leaf cushions are also known from other localities (see fig. 15 in Wagner et al. 2003) and may simply be the result of a different mode of preservation. Fortunately, the specimen from Orzesze has scars the shape of which is typical for leaf scars of vegetative stems whereas sporophylls left on the pseudo-leaf cushions show a typical V-shaped scar. Therefore we interpret this specimen as a fragment of a vegetative stem of Omphalophloios (i.e. Bodeodendron). However, it is completely impossible to state whether this specimen belongs to $O$. orzeschensis or to some other described species. It also differs from all currently known vegetative stems. For 

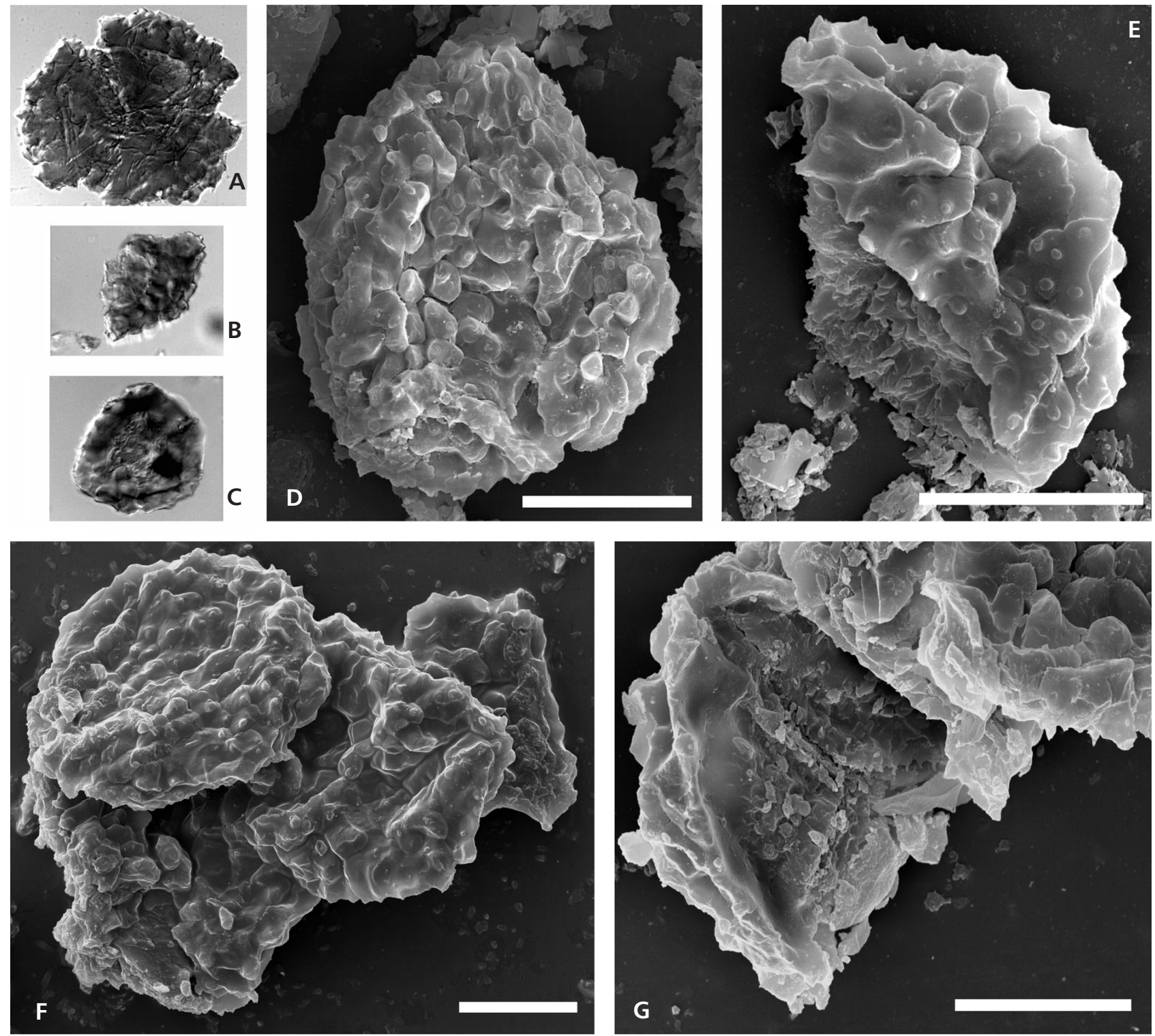

Figure 6. Omphalophloios orzeschensis (Bode) comb. nov. emend.; MB.Pb. 2003/0883. A - tetrade of in situ microspores of the Densosporites-type. $\times 500$. $\bullet \mathrm{B}-$ in situ microspore of the Densosporites-type. Lateral view showing the difference between conate sculpture of the distal surface (lower part of the specimen) and smooth proximal surface (upper part of the specimen). $\times 500 . \bullet \mathrm{C}-$ in situ microspores of the Densosporites-type. Proximal view. $\times 500$. $\bullet \mathrm{D}$ - in situ microspore of the Densosporites-type. Distal surface with conate to rugulate sculpture. Scale bar $25 \mu \mathrm{m}$. SEM. $\bullet$ E - in situ microspore of the Densosporites-type. Lateral view showing the difference between the strongly spinate, conate sculpture of the distal surface (right) and spinate proximal surface (left). Scale bar $20 \mu \mathrm{m}$. SEM. $\bullet \mathrm{F}$ - in situ microspores of the Densosporites-type. Note strongly conate sculpture of the distal surfaces. Scale bar $25 \mu \mathrm{m}$. SEM. $\bullet \mathrm{G}$ - two in situ microspores of the Densosporites-type. Note strongly conate sculpture of the distal surface on the left specimen and laevigate, finely scabrate to spinate proximal surface with trilete mark on the right specimen. Scale bar $20 \mu \mathrm{m}$. SEM.

this reason we assign this specimen to a new species, Omphalophloios bodei sp. nov.

The presence of a depression above some of the leaf scars is interesting as it resembles a ligule pit. Leisman (1970) made similar observations indicating the possible presence of a ligule on a permineralized specimen of Sporangiostrobus kansanensis. Whether or not this is really a ligule pit, could be confirmed by its presence on other findings from different localities.
Comparison. - This specimen is interpreted as a vegetative stem fragment of Omphalophloios, i.e. Bodeodendron. Unfortunately, all the vegetative axes of other species so far known (O. puertollanense, O. cyclostigma, O. anglicus), are of more or less similar size and morphology. However, most of them display apparently raised leaf cushions, although specimens with flat leaf cushions are also known (Wagner \& Spinner 1976), probably as a result of the mode of preservation. Most of species display rhomboidal leaf cushions with 

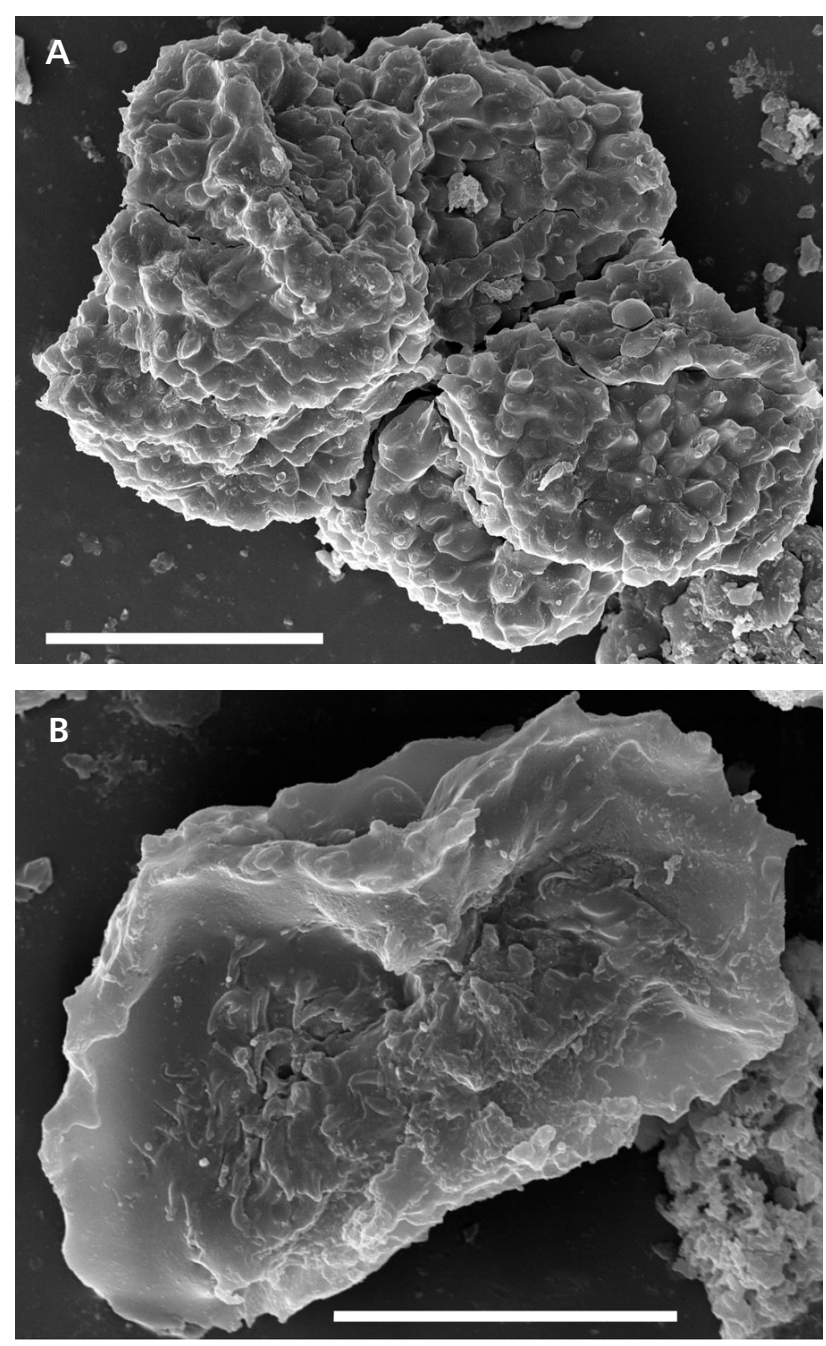

Figure 7. Omphalophloios orzeschensis (Bode) comb. nov. emend. - A - in situ microspores of the Densosporites-type. Note strongly conate sculpture on the distal surfaces. Scale bar $50 \mu \mathrm{m}$. SEM. - B - in situ microspore of the Densosporites-type. Note laevigate sculpture on the proximal surface of the cingulum and spinate sculpture on the proximal surface of the central body with trilete mark. Scale bar $20 \mu \mathrm{m}$. SEM.

acute upper and lower ends. In addition, lateral angles may be rounded and acute even within one species (Wagner \& Spinner 1976, Wagner 1989). The leaf scar is usually subtriangular to bell-shaped or even rounded in some species.

The specimen from Orzesze described here is most similar to O. puertollanense from the Stephanian $\mathrm{C}$ of Puertollano in central Spain. Leaf cushions of $O$. puertollanense are between 7 and $8 \mathrm{~mm}$ wide and between 13 and $17 \mathrm{~mm}$ long depending both on preservation and position on the stem. Its leaf scar is subtriangular or bell-shaped, located in the middle of a smooth leaf cushion which lacks keels and parichnos markings. It is about $4-5 \mathrm{~mm}$ wide and $4 \mathrm{~mm}$ long. All these features significantly resemble the Polish specimen except that its leaf cushions are not so raised and margins less pronounced plus the leaf cushions of the Span- ish species are generally larger. However, the amount of flattening and, therefore, relief of leaf cushions, it is largely a taphonomic character and only very fresh stem material will show raised leaf cushions as do the specimens preserved in volcanic ash (Wagner et al. 2003, Wagner, pers. comm.). Another important factor is also the quite large stratigraphic difference between these two species (about $10 \mathrm{Ma}$ ).

A comparison of $O$. bode $i$ with $O$. cyclostigma from the middle Westphalian of the USA and $O$. anglicus from the middle and late Westphalian of western Europe shows only slight differences. The American species has about $15 \mathrm{~mm}$ long and $8 \mathrm{~mm}$ wide raised and slightly asymmetrical leaf cushions with the upper and lower ends gently inflected in opposite directions. The leaf scar is bell-shaped to nearly rounded, 3.5-4 $\mathrm{mm}$ wide and about $3.5 \mathrm{~mm}$ long, also located in the middle of leaf cushion. Apart from the slightly larger size of the leaf cushions, the American $O$. cyclostigma differs from $O$. bodei in having generally smaller and more rounded leaf scars. A comparison with the west European $O$. anglicus is based on specimens stored in the palaeontological collection at the Natural History Museum in London which were studied by one of authors (SO). O. anglicus has smooth, raised to flat, slightly asymmetrical leaf cushions with rounded lateral angles and acute upper and lower ends. The leaf scar, located in the middle of leaf cushion, is between $3-4.5 \mathrm{~mm}$ across (i.e. wide or long) and differs from $O$. bode $i$ in having a rounded to slightly oval shape. In some specimens it is a little longer than wide but may be vice versa in others.

\section{Summary and conclusion}

Re-examination of fossil plant collections from the Upper Silesian Coal Basin, deposited in the Museum für Naturkunde in Berlin, provided three specimens which belong to the lycopsid genus Omphalophloios. Two of these are Bode's (1928) type specimens of S. orzeschensis and S. rugosus. However, since Bode's description, significant progress has been made in the understanding of the systematic affinity and morphology of these plants.

Omphalophloios represents a very conservative lycopsid genus which displays only very small differences among particular species spanning most of the Pennsylvanian period. This concerns not only the whole plant morphology but also details such as leaf cushions, sporangia and in situ spores (Wagner \& Spinner 1976). It is difficult to find reliable features to distinguish particular species, especially if represented only by fragmentary material. This is also the case of the three specimens re-examined from the Orzesze Beds (Duckmantian) in the Upper Silesian Coal Basin. Bode (1928) distinguished his two species on the basis of differences in microspore sculpture. However, re-examination of in situ microspores under 

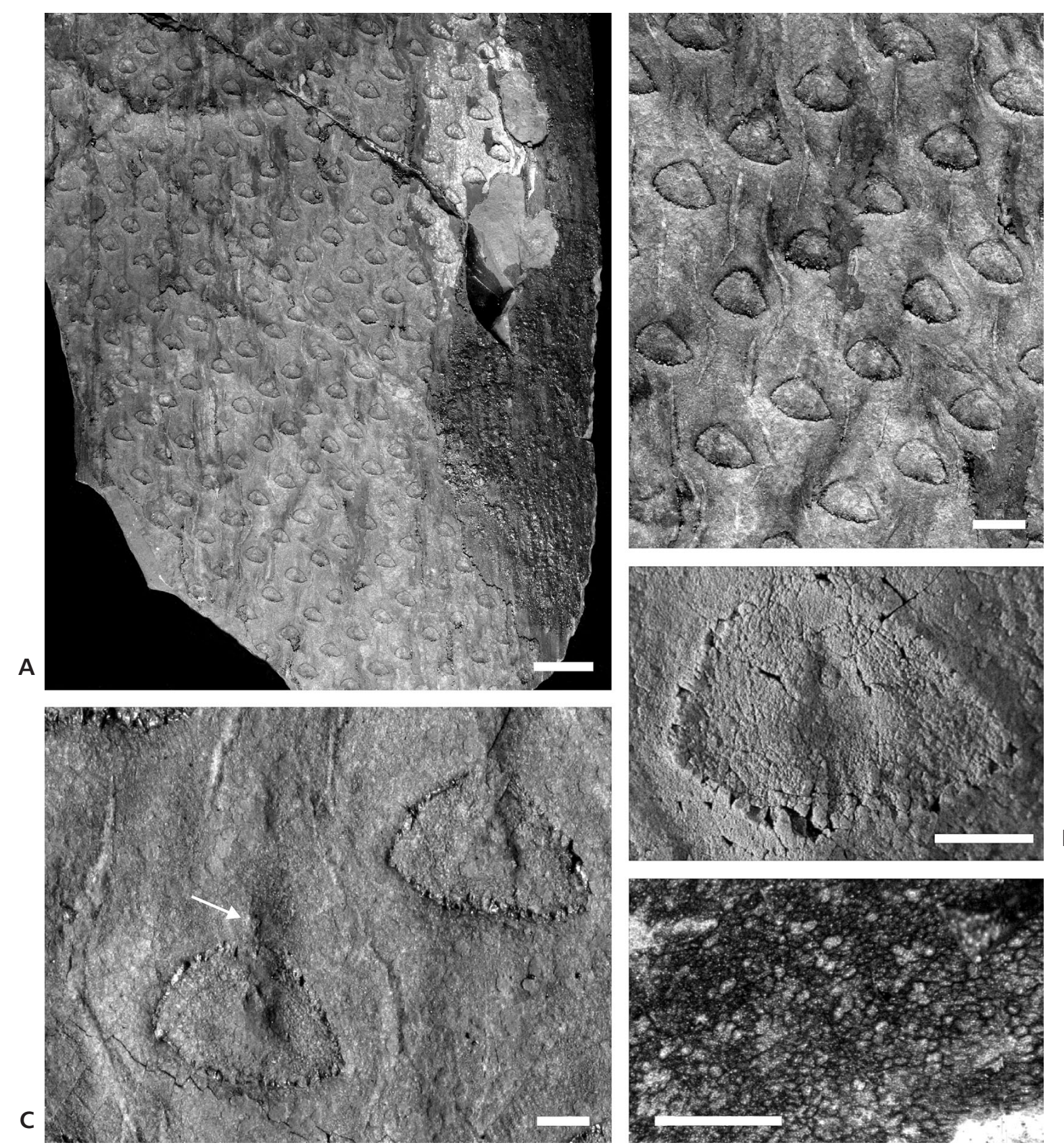

Figure 8. Omphalophloios bodei sp. nov. • A - view of the holotype (Inv. No. MB.Pb2009/0047). B - detail of leaf cushions arranged into ortostichies. Scale bar $3 \mathrm{~mm} . \cdot \mathrm{C}$ - detail of leaf cushion with leaf scar. Arrow indicates sharply defined depression which may indicate the position of ligule pit. Scale bar $1 \mathrm{~mm}$. D - detail of leaf scar and adjacent part of leaf cushion showing a smooth surface and vascular bundle scar (leaf trace) in lower part of the leaf scar. Scale bar $1 \mathrm{~mm}$. E - cell pattern on the surface of the leaf cushion. Scale bar $0.5 \mathrm{~mm}$. SEM, low vacuum.

SEM shows that there is no significant difference between in situ microspores of these two specimens, and, therefore, Bode's distinction between the two different species based on palynological criteria cannot be maintained. An attempt to find additional criteria which might justify retaining both species was not successful. Sporangial wall cells show similar polygonal patterns and a similar range in cell size variation. Therefore Bode's species are here synonymised. A new combination, O. orzeschensis, is proposed. This new combi- nation is based on the recognition that Omphalophloios and Sporangiostrobus represent the same plant.

In addition to Bode's specimens as described previously, another specimen has been uncovered, which represents the remains of a vegetative stem of Omphalophloios. This specimen also comes from the same locality (Orzesze) as the fertile specimens, and probably belongs to the same plant. However, this cannot be proven. Therefore, it is described as a new species, $O$. bodei $\mathrm{sp}$. nov. 


\section{Acknowledgement}

This research received support from the SYNTHESYS Project financed by the European Community Research Infrastructure Action under the FP6 "Structuring the European Research Area" Programme. This support (DE-TAF - 2501) allowed the first two authors to visit and study the Carboniferous plant collection in the Humboldt Museum für Naturkunde in Berlin. Part of the research was supported by the Grant Agency of the Academy of Sciences of the Czech Republic IAA, project 300130503, the Institute of Geology in Prague research project (AVOZ30130516) and project MSM 0021620855 of the Faculty of Science. R.H. Wagner from the Jardin Botánico de Córdoba, Spain and B.A. Thomas from the University of Aberystwyth, Wales, UK, are thanked for their constructive review of the manuscript.

\section{References}

BEK, J. 1998. Spórové populace některých rostlin oddělení Lycophyta, Sphenophyta, Pteridophyta a Progymnospermophyta z karbonských limnických pánví České republiky. 505 pp. Ph.D. thesis, Geologický ústav Akademie věd České republiky. [in Czech]

BEK, J. 2008. Late Mississippian-early Pennsylvanian (Serpukhovian-Bashkirian) miospore assemblages of the Bohemian part of the Upper Silesian Basin, Czech Republic. Review of Palaeobotany and Palynology 152, 40-57.

DOI 10.1016/j.revpalbo.2008.04.008

BeK, J. \& OPLUŠTIL, S. 1998. Some lycopsid, sphenopsid and pteropsid fructifications and their miospores from the Upper Carboniferous basins of the Bohemian Massif. Palaeontographica, Abteilung B 248, 127-161.

BeK, J. \& StRAKOVÁ, M. 1995. Carboniferous fertile branch Sporangiostrobus feistmantelii (O. Feistmantel) Němejc and its miospores from the Kladno Basin, Bohemian Massif. Acta Musei nationalis Pragae, Series B 51(1-4), 37-51.

BhARADWAJ, D.A. 1958. On Porostrobus zeilleri Nathorst and its spores with remarks on the systematic position of $P$. benholdi Bode and phylogeny of Densosporites Berry. The Palaeobotanist 7, 67-75.

BODE, H. 1928. Über eine merkwürdige Pteridophytenfruktifikation aus dem oberschlesischen Carbon. Jahrbuch der Preußischen Geologischen Landesanstalt 49, 245-247.

Brousmiche-Delcambre, C., Coquel, R. \& Wagner, R.H. 1995. Nouvelle interprétation du genre Omphalophloios White, 1898 (Lycophyte primitive). Comptes rendus, Académie des Sciences, Paris, 321(II a), 179-184.

CHALONER, W.G. 1956. On Sporangiostrobus langfordii sp. nov., a new fossil lycopod cone from Illinois. American Midland Naturalist 55, 437-442. DOI 10.2307/2422605

ChALONER, W.G. 1962. A Sporangiostrobus with Densosporites microspores. Palaeontology 5(1), 73-85.

ChALONER, W.G. 1967. Lycophyta, 435-802. In Boureau, E. (ed.) Traité de Paléobotanique, II, Bryophyta, Psilophyta, Lycophyta. Masson, Paris.

Coquel, R. \& Brousmiche-Delcambre, C. 1996. Comparaisons spores in situ - spores dispersées chez quelques Equisétales, Marattiales et Lépidodendrales du Carbonifère supérieur: Considérations sur l'utilisation de morphoespéces en paléopalynologie. Revue de Paléobiologie 15(1), 121-154.

DetTmann, M.E. 1963. Upper Mesozoic microfloras from south-eastern Australia. Proceedings of the Royal Society of Victoria $77,1-148$.
EBLE, C.F. \& GRADY, W.C. 1990. Paleoecological interpretation of a Middle Pennsylvanian coal bed from the central Appalachian Basin, U.S.A. International Journal of Coal Geology 16, 255-286. DOI 10.1016/0166-5162(90)90054-3

FEISTMANTEL, O. 1876. Die Versteinerungen der böhmischen Kohlenablagerungen. Palaeontographica 23, 7. Lieferung, 223-262.

LEISMAN, G.A. 1970. A petrified Sporangiostrobus and its spores from the Middle Pennsylvanian of Kansas. Palaeontographica, Abteilung B 129(4-6), 166-177.

LITTKE, R. 1987. Petrology and genesis of Upper Carboniferous seams from the Ruhr region, West Germany. International Journal of Coal Geology 7, 147-184.

DOI 10.1016/0166-5162(87)90047-4

NĚMEJC, F. 1931. A study on the systematic position of the fructification called Sporangiostrobus Bode. Bulletin international de l'Académie des Sciences de Bohême, 1-13.

OPLUŠTIL, S., SÝKOROVÁ, I. \& BEK, J. 1999. Sedimentology, coal petrology and palynology of the Radnice Member in the S-E part of the Kladno-Rakovník Basin, Central Bohemia (Bolsovian). Acta Universitatis Carolinae, Geologica 43, 599-623.

PotoniÉ, R. \& KREMP, G. 1954. Die Gattungen der Palaözoischen Sporae dispersae und ihre Stratigraphie. Geologisches Jahrbuch 69, 111-193.

PotoniÉ, R. \& KREMP, G. 1955. Die Sporae dispersae des Ruhrkarbons ihre Morphographie und Stratigraphie mit Ausblicken auf Arten anderer Gebiete und Zeitabschnitte. Teil I. Palaeontographica, Abteilung B 98, 1-136.

Punt, W., Hoen, P.P., Blackmore, S., Nilsson, S. \& LEThOMAS, A. 2007. Glossary of pollen and spore terminology. Review of Palaeobotany and Palynology 143, 1-81. DOI 10.1016/j.revpalbo.2006.06.008

REMY, W. \& REMY, R. 1975. Sporangiostrobus puertollanensis $n$. sp. und Puertollania sporangiostrobifera n. gen., n. sp. aus dem Stefan von Puertollano, Spanien. Argumenta Palaeobotanica 4, 13-29.

SCOTT, D.H. 1909. Studies in Fossil Botany, $2^{\text {nd }}$ edition. 552 pp. A. \& C. Blafl Ltd., London.

SMITH, A.H.V. 1962. The palaeoecology of Carboniferous peats based on the miospores and petrography of bituminous coals. Proceeding of Yorkshire Geological Society 33, 423-474.

SMith, A.H.V. \& BUTTERWORTH, M.A. 1967. Miospores in the coal seams of the Carboniferous of Great Britain. Special Papers in Palaeontology 1, 1-324.

STREHLAU, K. 1990. Facies and genesis of Carboniferous coal seams of Northwest Germany. International Journal of Coal Geology 15, 245-292. DOI 10.1016/0166-5162(90)90068-A

THOMAS, B.A. \& BRACK-HANES, S.D. 1984. A new approach to family grouping in the lycophytes. Taxon 33, 247-255. DOI 10.2307/1221165

WAGNER, R.H. 1989. A late Stephanian forest swamp with Sporangiostrobus fossilized by volcanic ash fall in the Puertollano Basin, central Spain, International Journal of Coal Geology 12, 523-552. DOI 10.1016/0166-5162(89)90064-5

WAGNER, R.H., BRousmiche-DelcAmbre, C. \& COQuel, R. 2003. Una Pompeya Paleobotánica: historia de una marisma carbonífera sepultada por cenizas volcánicas, 448-475. In Nuche, R. (ed.) Separata de Patrimonio Geológico de Castilla-La Mancha. Enresa, Madrid.

WAGNER, R.H. \& SPINNER, E. 1976. Bodeodendron, tronc associé à Sporangiostrobus. Comptes rendus, Académie des Sciences, Paris, Série D, Sciences naturelles 282, 353-356.

WHITE, D. 1898. Fossil flora of the Lower Coal Measures of Missouri. Monographs of the United States Geological Survey 37, $1-467$. 